\title{
Investigations on age, growth and mortality parameters of Ailia coila (Hamilton, 1822) (Siluriformes: Ailiidae) from Brahmaputra river system of Assam, India
}

\author{
PRANAB GOGOI ${ }^{1}$, SURENDRA KUMAR AHIRWAL ${ }^{2 *}$, S. K. CHAKRABORTY ${ }^{3}$, \\ B. K. BHATTACHARJYA ${ }^{4}$, A. K. JAISWAR ${ }^{3}$, JASPREET SINGH ${ }^{2}$ AND P. R. BEHERA ${ }^{1}$ \\ ${ }^{1}$ ICAR-Central Inland Fisheries Research Institute, Kolkata Centre, C.G.O. Complex, Salt Lake City, Kolkata - 700064 \\ West Bengal, India \\ ${ }^{2}$ ICAR-Research Complex for Eastern Region, Division of Livestock and Fishery Management, Patna - 800014 \\ Bihar, India \\ ${ }^{3} I C A R$-Central Institute of Fisheries Education, Versova, Andheri (W), Mumbai - 400 061, Maharashtra, India \\ ${ }^{4}$ ICAR-Central Inland Fisheries Research Institute, Regional Centre, HOUSEFED Complex, Guwahati - 781006 \\ Assam, India \\ e-mail: surendraahirwal@gmail.com
}

\begin{abstract}
The present study deals with the detailed investigation on population dynamics of the near-threatened catfish Ailia coila (Hamilton, 1822), which inhabits the Brahmaputra River of India and forms an important component of freshwater inland fishery, providing nutritional and financial security to the local community. A total of 1034 individuals were collected by weekly sampling from the Uzanbazar and Dhubri landing centres of this river system from September 2013 to April 2014. The estimated asymptotic length $\left(\mathrm{L}_{\infty}\right)$, growth coefficient $(\mathrm{K})$ and age at zero length $\left(\mathrm{t}_{0}\right)$ of $A$. coila were $268 \mathrm{~mm}, 0.87 \mathrm{yr}^{-1}$ and $\mathrm{t}_{0}=0.000028$ years respectively. Estimated total mortality $(\mathrm{Z})$, natural mortality $(\mathrm{M})$ and fishing mortality coefficient (F) were 5.76, 1.63 and $4.13 \mathrm{yr}^{-1}$ respectively. Using von Bertalanffy growth formula (VBGF) the length attained at the end of first, second and third years of life were estimated at 156, 221 and $248 \mathrm{~mm}$, respectively. The von Bertalanffy growth equation of this fish can be written as $\mathrm{L}_{\mathrm{t}}=268\left\{1-\mathrm{e}^{-0.87(\mathrm{t}+0.000027866)}\right\}$. The exploitation ratio (U) and exploitation rate (E) and $\mathrm{M} / \mathrm{K}$ ratio were estimated at $0.71,0.72$ and 1.87 , respectively.
\end{abstract}

Keywords: Ailia coila, Asymptotic length, Fishing mortality, Growth co-efficient, M/K ratio

\section{Introduction}

The fisheries sector is a major supplier of high quality animal protein, supporting the livelihoods and well being of more than $12 \%$ of the world's population (FAO, 2020). Commercial fishing continues to be a major contributor to the economics of developing and developed countries. In addition to the large worldwide value of the catch, approximately 36 million people are employed in capture and culture fisheries activities (Lackey, 2005). India has $18 \%$ of the world population, with only $4 \%$ of the world's freshwater resources (Anon., 2018). Estimated total fish production during 2018-19 was 13.42 million $t$, of which 3.71 was from the marine sector and 9.71 from culture fisheries (Anon., 2019). Catfishes are one of the largest groups of teleosts containing around 6750 species under 38 families. The family Ailiidae contains 6 genera and 17 species. The genera are represented by Ailia, Ailiichthys, Clupisoma, Laides, Eutropiichthys and Proeutropiichthys (Fricke et al., 2020). Among these,
Ailia coila which is near-threatened (Habib et al., 2020) forms a major fishery among catfishes in the Brahmaputra river system. Found throughout the year, it is locally known as Kajoli or Bahpati in Assamese.

A sound knowledge of growth and age of species contributing to the fishery is essential for understanding the longevity of exploited stocks, age composition of the catch, age at sexual maturity, the suitability of different environments for growth, population dynamics and possible identification of stocks based on growth differences. It is also essential to determine the mortality and survival rate of various year classes and success of the yearly broods after recruitment. This would allow fishery managers to understand the dynamics of fish stocks and how fish populations would react to external pressures like commercial fishing and predation. Estimates of total mortality are used in stock assessments to determine sustainable harvest levels of exploited species and rebuilding plans for overexploited species. However, 
no information is available on age, growth and mortality parameters of $A$. coila from the Brahmaputra River. Therefore, the present study was carried out to generate information on the growth, mortality and population parameters of $A$. coila from Brahmaputra river system to form baseline data for developing fishery management plans for the resource.

\section{Materials and methods}

Sampling

A total of 1034 fish samples were collected through weekly sampling from drift gillnets, river shore seines and drag nets $(8.2 \mathrm{~mm})$ operated off Uzanbazar, Guwahati $\left(26^{\circ} 11^{\prime} 43.25^{\prime \prime} \mathrm{N} ; 91^{\circ} 45^{\prime} 20.90^{\prime \prime} \mathrm{E}\right)$ and Dhubri landing centre, Dhubri $\left(26^{\circ} 01^{\prime} 23.62^{\prime \prime} \mathrm{N} ; 8^{\circ} 59^{\prime} 31.72^{\prime \prime}\right.$ E) of
Brahmaputra River in Assam (Fig. 1). The length range of the sampled fishes was 63-166 mm total length (TL).

\section{Growth parameters}

All collected specimens were placed in insulated ice boxes and transported to the laboratory where they were screened, cleaned and identified with the help of established keys (Day, 1878; Talwar and Jhingran, 1991; Nelson 2006). The fishes were measured for TL from the tip of the snout to the tip of the caudal fin to the nearest $1 \mathrm{~mm}$ using a digital measuring scale (Mitutoyo: CD-6"ASX) and wet weight was recorded to the nearest $1 \mathrm{~g}$ using a digital balance (Fig. 2).

The length frequency data were distributed at $10 \mathrm{~mm}$ class intervals, frequency raised for the day and

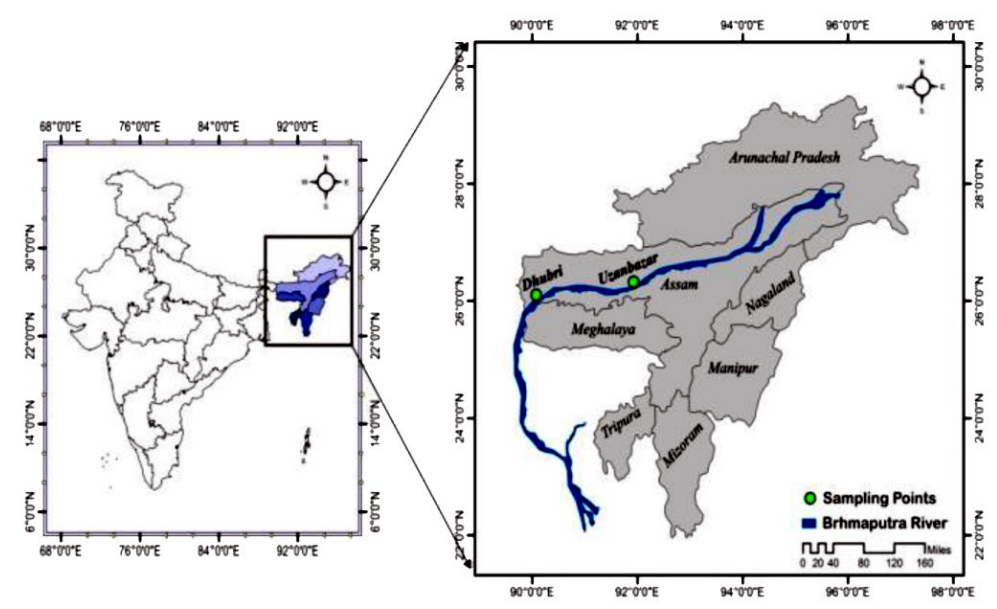

Fig. 1. Map showing the sampling places along the Brahmaputra river system

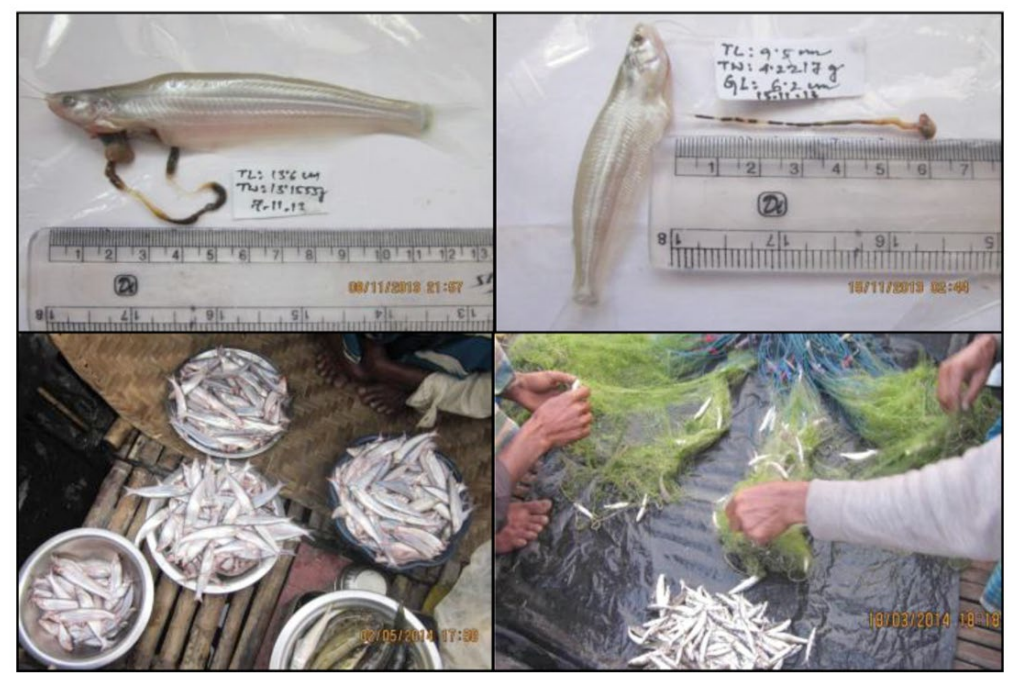

Fig. 2. Sampling and segregation of different length groups 
subsequently for the month (Sekharan, 1962). Several methods such as modal progression analysis, Ford-Walford and computer-based FiSAT programme, ELEFAN, Bhattacharya analysis (Bhattacharya, 1967) as well as Gulland and Holt plot (Gulland and Holt, 1959) were used to estimate the growth parameters. In Bhattacharya's method, the composite distribution was separated to the normal distribution to represent the cohorts. Gulland and Holt's plot further refined the preliminary estimates made by Bhattacharya's method. Intercept ' $a$ ' and slope ' $b$ ' provided the $\mathrm{K}$ and $\mathrm{L}_{\infty}$ through the relationship: $\mathrm{K}=-\mathrm{b}$ and $\mathrm{L}_{\infty}=-\mathrm{a} / \mathrm{K}$, and an analysis was done using FiSAT programme (Gayanilo et al., 1996). The age at zero length $\left(\mathrm{t}_{0}\right)$ of von Bertalanffy growth formula (VBGF) was estimated using the equation: $-\ln [1-\mathrm{L}(\mathrm{t}) / \mathrm{L} \infty)]=-\mathrm{K}^{*} \mathrm{t}_{0}+$ $\mathrm{K} * \mathrm{t}$, with a series of length at age data and an estimate of $\mathrm{L}_{\infty}$, the intercept ' $\mathrm{a}$ ' and ' $\mathrm{b}$ ' were calculated to obtain the $\mathrm{K}$ and $\mathrm{t}_{0}$ as: $\mathrm{K}=\mathrm{b}$ and $\mathrm{t}_{0}=-\mathrm{a} / \mathrm{b}$ (Bertalanffy, 1934).

\section{Mortality parameters}

Estimates of instantaneous mortality Z were obtained through different methods (Beverton and Holt, 1957; Jones and Van Zalinge, 1981; Pauly, 1984). Natural mortality was estimated by the formula of Pauly given as: $\ln \mathrm{M}=-0.0152-0.279 \ln \mathrm{L}_{\infty}+0.6543 \ln \mathrm{K}+0.463 \ln \mathrm{T}$, where $\mathrm{L}_{\infty}$ is in $\mathrm{cm}, \mathrm{K}$ annual and $\mathrm{T}$ is the mean environmental temperature taken in degree celsius (Pauly, 1980). Estimates of natural mortality were also obtained by other methods for comparison (Taylor, 1960; Cushing, 1968; Alagaraja, 1984; Srinath, 1998). Fishing mortality (F) was estimated by subtracting natural mortality (M) from total mortality (Z).

\section{Exploitation rate and ratio}

Exploitation rate $(\mathrm{E})$ was calculated as $\mathrm{E}=\mathrm{F} / \mathrm{Z}$ and the exploitation ratio $(\mathrm{U})$ was calculated by $\mathrm{U}=\mathrm{F} / \mathrm{Z}^{*}$ $\left(1-\mathrm{e}^{-\mathrm{Z}}\right)$ (Beverton and Holt, 1957).

\section{Results}

\section{Growth parameters}

In scatter diagram technique, seven identical curves could be drawn by tracking the progression of modes and growth was read at random intervals for the calculation of $\mathrm{L}_{\infty}$ and $\mathrm{K}$. Asymptotic length and growth coefficient were estimated at $265 \mathrm{~mm}$ and $0.84 \mathrm{yr}^{-1}$, respectively (Fig. 3). In Ford-Walford plot, by employing monthly mean length, calculated asymptotic length and growth coefficient value were similar to that estimated by modal progression. Linking of means was done by the Bhattacharya method using FiSAT programme after separating the Gaussian components and the estimated values of $\mathrm{L}_{\infty}$ and $\mathrm{K}$ were $264.35 \mathrm{~mm}$ and $0.74 \mathrm{yr}^{-1}$ respectively (Fig. 4).

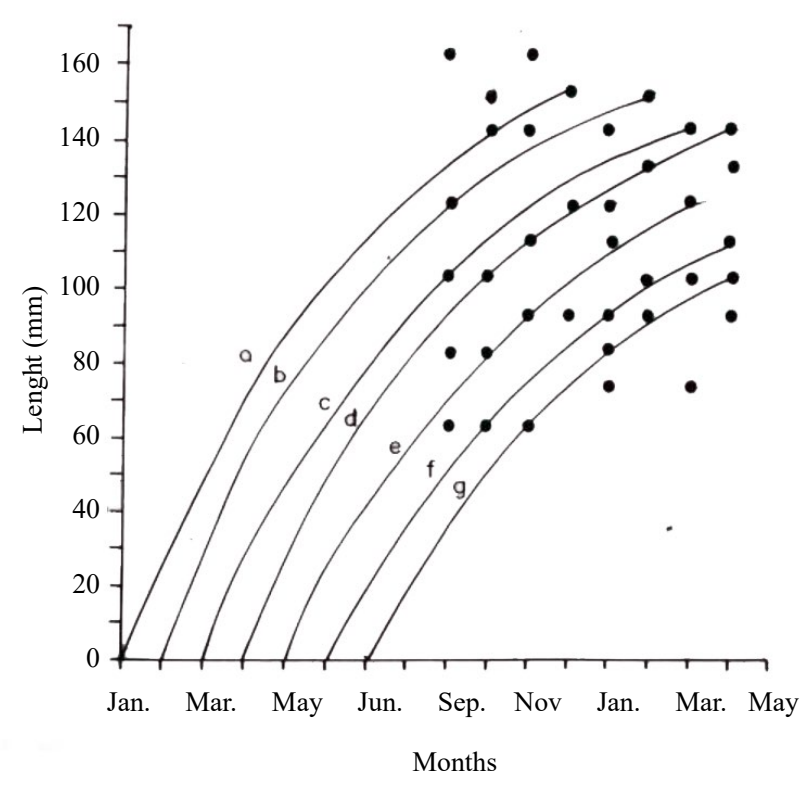

Fig. 3. Monthly modal progression analysis of $A$. coila

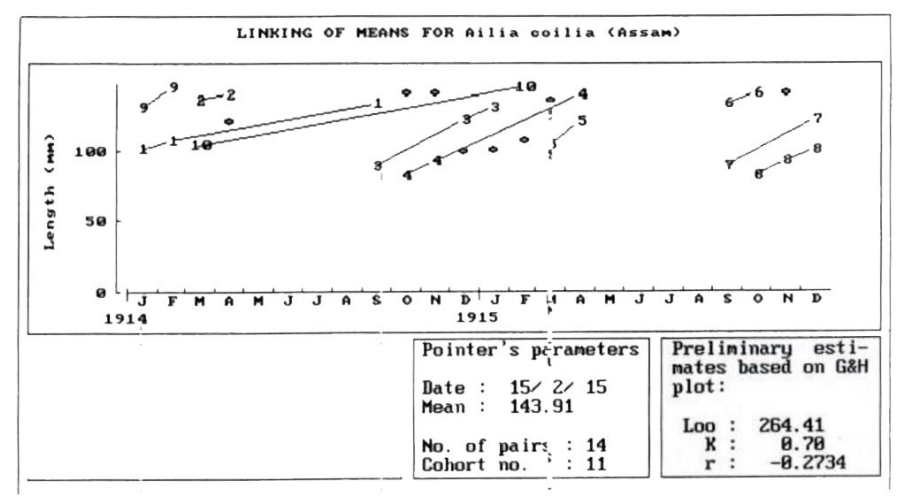

Fig. 4. Linking of means by employing Modal Progression Analysis (Bhattacharya method) for A. coila using FiSAT 
Data was further refined through employing Gulland and Holt plot of FiSAT programme and the values of $\mathrm{L}_{\infty}$ and $\mathrm{K}$ obtained were $265 \mathrm{~mm} 0.84 \mathrm{yr}^{-1}$. The ELEFAN technique gave the best fitting growth line with the goodness of fit value of $0.174 ; \mathrm{L}_{\infty}$ and $\mathrm{K}$ values were $268 \mathrm{~mm}$ and $0.87 \mathrm{yr}^{-1}$, respectively (Fig. 5). The value of age at zero length $\left(\mathrm{t}_{0}\right)$ using von Bertalanffy's plot and monthly mean length obtained by the scatter diagram technique was -0.000028 years.

The growth performance index $(\varnothing)$ was found to be 4.79 in the present study. Table 1 summarises the final estimates of growth parameters, mortality and longevity estimated

Age and growth

Using the growth parameters, the sizes attained by A. coila were estimated to be 156,221 and $248 \mathrm{~mm}$ at the end of first, second and third years of its life, respectively (Fig. 6). The maximum observed length of the fish in the fishery in the course of this study was $166 \mathrm{~mm}$ TL. Based on this, the estimated fishable life span of the species is 1.12 years.

\section{Mortality and exploitation}

Beverton and Holt method showed that the instantaneous rate of total mortality is $4.78 \mathrm{yr}^{-1}$, while Jones and Van Zalinge cumulative catch curve method estimated it at $6.27 \mathrm{yr}^{-1}$. Pauly's length converted catch curve method estimated its value at $5.76 \mathrm{yr}^{-1}$, which was considered for further calculations as it is one of the most widely used

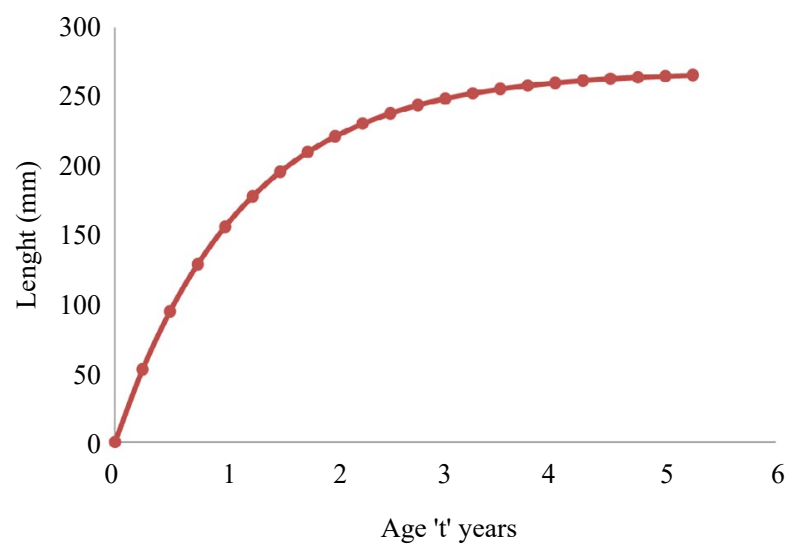

Fig. 6. Estimated von Bertalanffy's growth curve for A. coila

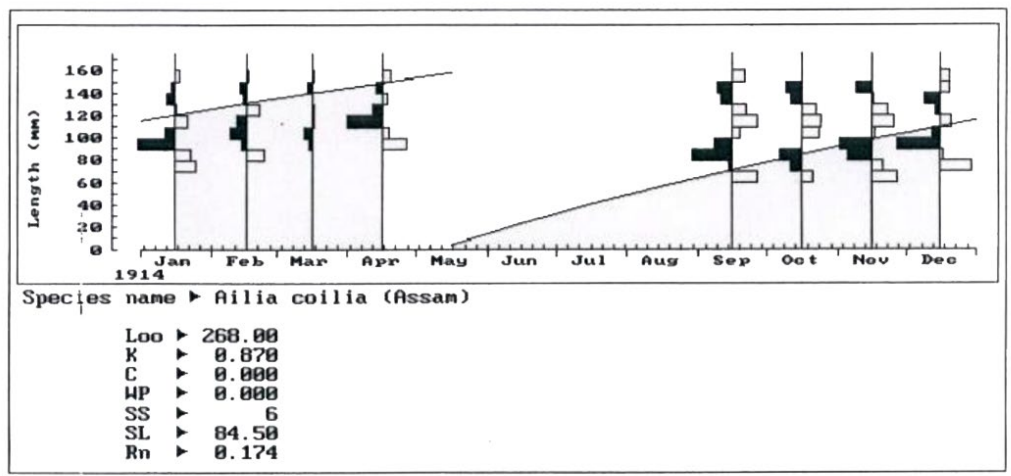

Fig. 5. ELEFAN curve of $A$. coila employing computer based FiSAT programme

Table 1. Yearly growth parameters of $A$. Coila from Brahmaputra river system

\begin{tabular}{ll}
\hline Population parameters & Estimated values \\
\hline Asymptotic length $\left(\mathrm{L}_{\infty}\right)$, ELEFAN FiSAT $(\mathrm{mm})$ & 268 \\
Growth coefficient $(\mathrm{K})$, ELEFAN FiSAT $\left(\mathrm{yr}^{-1}\right)$ & 0.87 \\
Age at zero length $\left(\mathrm{t}_{0}\right)$, von Bertalanffy's growth equation & -0.000027 \\
Total mortality $(\mathrm{Z})\left(\mathrm{yr}^{-1}\right)$ & 5.76 \\
Natural mortality $(\mathrm{M})\left(\mathrm{yr}^{-1}\right)$ & 1.63 \\
Fishing mortality $(\mathrm{F})\left(\mathrm{yr}^{-1}\right)$ & 4.13 \\
M/K ratio & 1.87 \\
Exploitation rate $(\mathrm{E})=\mathrm{F} / \mathrm{Z}$ & 0.72 \\
Exploitation ratio $(\mathrm{U})=(\mathrm{F} / \mathrm{Z}) *\left(1-\mathrm{e}^{-\mathrm{Z}}\right)$ & 0.71 \\
Phi-prime $(\varphi=\log \mathrm{K}+2 \log \mathrm{L} \infty)$ & 4.79 \\
Length attained at the end of I, II,III year of life $(\mathrm{mm})$ & $156,221,248$ \\
Estimated fishable life span of fish (years) & 1.12 \\
\hline
\end{tabular}


methods in the tropics and the value obtained is nearest to the average value of " $Z$ " obtained by the other methods. Results presented in Table 2 indicate the value of natural mortality estimated by different methods. The value of $1.63 \mathrm{yr}^{-1}$ obtained by Pauly's method was used for further calculations. Fishing mortality (F), estimated by subtracting natural mortality $(\mathrm{M})$ from the total mortality coefficient (Z) was obtained as $4.13 \mathrm{yr}^{-1}$. Exploitation ratio (U), exploitation rate $(\mathrm{E})$ and $\mathrm{M} / \mathrm{K}$ ratio was estimated as 0.71 , 0.72 and 1.87 in the present study.

\section{Discussion}

\section{Growth parameters}

Age, growth and mortality parameters of a fish species provides information on life span, maturity, stock composition and their growth pattern. However, not much work has been done on age, growth and population parameters of $A$. coila and other species under this family from Brahmaputra River in Assam and other riverine waters of India. In the present study, a number of methods were used for the estimation of growth parameters, the values obtained from ELEFAN I of FiSAT programme $\left(\mathrm{L}_{\infty}, 268 \mathrm{~mm}\right.$ and $\left.\mathrm{K}, 0.87 \mathrm{yr}^{-1}\right)$ were considered reasonable and used as input parameters for estimation of other population parameters. The asymptotic length $\left(\mathrm{L}_{\infty}\right)$ and growth co-efficient $(\mathrm{K})$ was quite similar to the estimates of Abobi and Ekau (2013) for Schilbe intermedius $\left(\mathrm{L}_{\infty}=\right.$ $289, \mathrm{~K}=0.95 \mathrm{yr}^{-1}$ ) from Volta River of Ghana. According to Pauly and Morgan (1987), higher values of $K$ are typically connected with lower values of $\mathrm{L}_{\infty}$ and vice versa, since these parameters are interrelated with each other i.e., smaller fishes usually have faster growth rates. The estimated value of $\mathrm{t}_{0}(-0.000028)$ indicated higher growth rate in early life stages as compared to adult size; $A$. coila was found to attain a length of 156, 221 and $248 \mathrm{~mm}$ after completion of first, second and third years of its life, respectively. Growth rate was much higher in the first and second years. Ahirwal et al. (2018) observed that the lower length group of fishes feed actively and more frequently than the larger length group; this may be due to high food requirements in the younger stage. In the present study, the growth performance index $(\varnothing)$ was 4.79 , which was found similar to the observation made by Prasad et al. (2012) on Horabagrus brachysoma (4.89) from Periyar River of southern Western Ghats, India.

\section{Mortality parameters}

The estimated values of total mortality (Z), fishing mortality (F) and natural mortality (M) were 5.76, 4.13 and $1.63 \mathrm{yr}^{-1}$, respectively. Mortality parameters may not stop at a stable level and are liable to change from time to time depending on supply of good quality food, maturation and spawning period of fishes (Bagenal and Tesch, 1978; Sparre and Venema, 1992). This is the first study documenting growth and mortality parameters of $A$. coila and there is no documented information on mortality parameters of $A$. coila and other species under this family, hence, a comparative assessment of the estimates cannot be made. The estimated $\mathrm{M} / \mathrm{K}$ ratio of 1.87 falls within the range $1.5-2.5$, given by Beverton and Holt (1956) for the accurate estimation of natural mortality coefficient, indicating that the estimates of both $\mathrm{M}$ and $\mathrm{K}$ done in the present study are reasonable and reliable.

\section{Exploitation rate and ratio}

The current exploitation rate and ratio of $A$. coila are similar (0.72 and 0.71). Gulland (1971) stated that for the optimal exploitation of a stock, it is assumed that exploitation rate (E) should be equal to 0.5 for optimising the sustainable yield when the fishing and natural mortality is quite similar. In the present study, as both, the exploitation rate and ratio were above 0.5 and the fishing mortality was higher than the natural mortality., it can be concluded that the population of $A$. coila in Brahmaputra River is overexploited. One of the reasons for overexploitation of this resource may be its high market price ( $₹ 400-800 \mathrm{~kg}^{-1}$ ). Of late, the catch of this species has also declined due to indiscriminate fishing of juveniles through the deployment of small mesh sized gillnets, river shore seines and drag nets. The present study provides basic information required to initiate management practices for sustainable fishery of the resource in the Brahmaputra River. While strict management practices like protected waters, mesh size regulations, restriction of non-selective gears, destructive fishing and restricting the discharge of untreated effluents into the natural water bodies are immediate options, the study also warrants close monitoring and assessment

Table 2. Estimated values of natural mortality coefficient " $M$ " by different methods

\begin{tabular}{ll}
\hline Method applied & Natural mortality (M) \\
\hline Cushing's method (Cushing, 1968). & $1.97 \mathrm{yr}^{-1}$ \\
Taylor's method (Taylor, 1960). & $1.30 \mathrm{yr}^{-1}$ \\
Pauly's empirical method (Pauly, 1980). & $1.63 \mathrm{yr}^{-1}$ \\
Alagaraja's method (Alagaraja, 1984). & $1.97 \mathrm{yr}^{-1}$ \\
Srinath's empirical formula (Srinath, 1998). & $1.46 \mathrm{yr}^{-1}$ \\
\hline
\end{tabular}


of the resource for a continued period of time until the exploitation levels are considerably reduced.

\section{Acknowledgements}

The authors thank the Director, ICAR-CIFE, Mumbai for providing facilities to carry out the research work. Authors are also thankful to the Director, ICAR-CIFRI, Barrackpore for providing laboratory facilities at Regional Centre of ICAR-CIFRI, Guwahati.

\section{References}

Abobi, S. M. and Ekau, W. 2013. Growth, mortalities and exploitation rates of Alestes baremoze (Joannis, 1835), Brycinus nurse (Ruppell, 1832) and Schilbe intermedius (Rupell, 1832) from lower reaches of the White Volta River (Yapei), Ghana. J. Agric. Biodivers. Res., 2(1): 1-10.

Ahirwal, S. K., Jaiswar, A. K. and Chakraborty, S. K. 2018. Diet composition of oil sardine, Sardinella longiceps (Valenciennes, 1847) from Mumbai waters of Maharashtra, India. Indian J. Mar. Sci., 47(09): 1880-1887.

Alagaraja, K. 1984. Simple methods for estimation of parameters for assessing exploited fish stocks. Indian J. Fish., 31(2): 177-208.

Anon. 2018. Study of assessment of water foot prints of India's long term energy scenarios. The Energy Research Institute, New Delhi, India, 8 pp.

Anon. 2019. Pocket book of agricultural statistics. Department of Agriculture, Cooperation and Farmers Welfare, Ministry of Agriculture and Farmers Welfare, Govt. of India, New Delhi, India, 43 pp.

Bagenal, T. B. and Tesch, F. W. 1978. Age and growth. In: Methods for assessment of fish production in freshwaters. International Biological Programme Hand book, No. 3. Blackwell Scientific Publications, UK, p. 159-181.

Bertalanffy, L. V. 1934. Investigations into the legality of growth, Part I: General basics of the theory; mathematical and physiological laws of growth in aquatic animals. Wilhelm Roux' Archive for Development Mechanics of Organisms, 131: 613-653. doi: 10.1007/BF00650112. (In German).

Beverton, R. J. H. and Holt, S. J. 1956. A review of method for estimating mortality rates in exploited fish population, with special reference to source of bias in catch sampling. Rapp. P.-v. Reun cons. Int. Explor. Mer., (1): 67-83.

Beverton, R. J. H. and Holt, S. J. 1957. On the dynamics of exploited fish populations. Fishery Investigations Series II, 19. Ministry of Agriculture, Fisheries and Food, London, UK, 533 pp.

Bhattacharya, C. G. 1967. A simple method of resolution of a distribution into Gaussian components. Biometrics, 23: 115-135. https://doi.org/10.2307/2528285.

Cushing, D. H. 1968. A study in population dynamics, University of Wisconsin Press, Madison, USA, 200 pp.

Day, F. 1878. The fishes of india being a natural history of fishes known to inhabit the seas and freshwaters of India, Burma and Ceylon. Bernard Quaritch, London, UK, 778 pp.
FAO 2020. The state of world fisheries and aquaculture: Sustainability in action. Food and Agriculture Organisation of the United Nations, Rome, Italy, $7 \mathrm{pp}$. https://doi. org/10.4060/ca9229en.

Fricke, R., Eschmeyer, W. N. and Laan, V. D. 2020. Eschmeyer's catalog of fishes: Genera, species, references. Electronic version. California Academy of Sciences, USA.

Gayanilo, F. C. Jr., Sparre, P. and Pauly, D. 1996. The FAOICLARM Stock Assessment Tools (FiSAT), User's Guide. FAO Comp. info. Ser. (Fisheries). Food and Agriculture Organisation of the United Nations, Rome, Italy, 124 pp.

Gulland, J. A. 1971. The fish resources of the ocean, Fishing News (Books) Ltd., West Byfleet, UK, 255 pp.

Gulland, J. A. and Holt, S. J. 1959. Estimation of growth parameters for data at unequal time intervals. ICES J. Mar. Sci., 25(1): 47-49.

Habib, K. A., Neogi, A. K., Nahar, J. Oh., Lee, Y. H. and Kim, C. G. 2020. An overview of fishes of the Sundarbans, Bangladesh and their present conservation status. J. Threat. Taxa, 12(1): 15154-15172. DOI: https://doi.org/10.11609/ jott.4893.12.1.15154-15172.

Jones, R. and Van Zalinge, N. P. 1981. Estimation of mortality rate and populations size for shrimp in Kuwait waters. Kuwait Bull. Mar. Sci., (2): 273-288.

Lackey, R. and Robert, T. 2005. Fisheries: History, science, and management. John Wiley \& Sons Inc., New Jersey, USA, p. 121-129. DOI: 10.1002/047147844X.sw249.

Nelson, J. S. 2006. Fishes of the world, $4^{\text {th }}$ edn. John Wiley and Sons Inc., New Jersey, USA, p. 162-185.

Pauly, D. 1980. On the interrelationships between natural mortality, growth parameters and mean environmental temperature in 175 fish stocks. J. Int. Counc. Explor. Sea, 39(3): 175-192. https://doi.org/10.1093/icesjms/39.2.175.

Pauly, D. 1984. Length converted catch curve-A powerful tool for fisheries research in the tropics (Part II). International Centre for Living Aquatic Resources Management, Fishbyte, 2(1): 17-19.

Pauly, D. and Morgan, G. R. 1987. Length-based methods in fisheries research. Proceedings of the International Conference on the Theory and application of lengthbased methods for stock assessment, 11-16 February 1985, Mazzara del Vallo, Sicily, Italy, 468 pp.

Prasad, G., Ali Anvar, Harikrishnan, M. and Raghavan, R. 2012 Population dynamics of an endemic and threatened yellow catfish Horabagrus brachysoma (Gunther) from Periyar River, southern Western Ghats, India. J. Threat. Taxa, 4(2): 2333-2342.

Sekharan, K. V. 1962. On oil sardine fishery of the Calicut area during the year 1955-56 to 1958-59. Indian J. Fish., 9A(2): 679-700. 
Sparre, P. and Venema, S. C. 1992. Introduction to tropical fish stock assessment. Part I: Manual. FAO Tech. Pap., 306. Food and Agriculture Organisation of the United Nations, Rome, Italy, 376 pp.

Srinath, M. 1998. Empirical relationship to estimate the instantaneous rate of natural mortality. Indian J. Fish., 45(1): 7-11.
Talwar, P. K. and Jhingran, A. G. 1991. Inland fishes of India and adjacent countries. Oxford and IBH Publishing, New Delhi, India, p. 591-613.

Taylor, C. C. 1960. Temperature, growth and mortality - The Pacific cockle. ICES J. Mar. Sci., 26: 117-124. https://doi. org/10.1093/icesjms/26.1.117. 